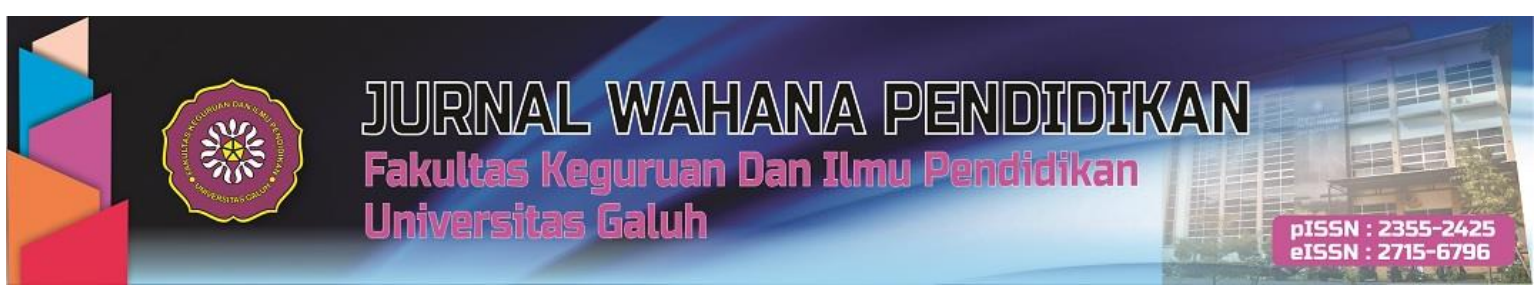

https://jurnal.unigal.ac.id/index.php/jwp/article/view/3587

\title{
SARKASME DALAM UNGGAHAN DAN KOMENTAR PADA GRUP FACEBOOK PT OY INDONESIA DAN IMPLIKASINYA TERHADAP PEMBELAJARAN BAHASA INDONESIA DI SMA
}

\author{
Agil Agung Attazky ${ }^{1}$, Leli Triana2 ${ }^{2}$, Syamsul Anwar ${ }^{3}$ \\ 1,2,3 Program Studi Pendidikan Bahasa Sastra Indonesia, Universitas Pancasakti Tegal \\ Email: Ielitriana99@gmail.com, syamsulanwar590@gmail.com
}

\begin{abstract}
The purpose of this study is to describe sarcasm in uploading and commenting on the Facebook group PT Oy Indonesia and describe the implications on learning Indonesian in high school. This study used a descriptive qualitative approach. Sources of data in this study came from the PT Oy Indonesia Facebook Group. The form of data in this study was the utterance of sarcasm in the PT Oy Indonesia Facebook Group. Data collection techniques used in this study was the note technique. The technique of presenting the results of the data analysis used was the informal method. The data analysis method used was the pragmatic matching method. The results showed that there were sarcasm in the form of: (1) sarcasm, (2) sarcasm of action, and (3) sarcasm. Sarcasm has the intention of insinuating and cursing, and has the function of affirmation, opinion and questions. The results of this study are implied in Indonesian language lessons in class XI high school at KD 3.24 to reconstruct the lecture text.
\end{abstract}

Keywords: Sarcasm, PT Oy Indonesia's Facebook Group, implied in lessons in high school

\section{ABSTRAK}

Tujuan penelitian ini adalah mendeskripsikan sarkasme dalam unggahan dan komentar pada grup Facebook PT Oy Indonesia dan mendeskripsikan implikasi hasil penelitian terhadap pembelajaran bahasa Indonesia di SMA. Penelitian ini menggunakan pendekatan kualitatif deskriptif Sumber data dalam penelitian ini berasal dari Grup Facebook PT Oy Indonesia. Wujud data dalam penelitian ini adalah tuturan sarkasme dalam Grup Facebook PT Oy Indonesia. Teknik pengumpulan data yang dilakukan dalam penelitian ini menggunakan teknik simak catat. Teknik penyajian hasil analisis data yang digunakan adalah metode informal. Metode analisis data yang digunakan adalah metode padan pragmatis. Hasil penelitian menunjukan bahwa terdapat sarkasme berbentuk: (1) sarkasme sifat (2) sarkasme tindakan, dan (3) sarkasme sebutan. Sarkasme tersebut memiliki maksud menyindir dan mengumpat, serta memiliki fungsi penegasan, pendapat dan pertanyaan. Hasil penelitian ini diimplikasikan dalam pelajaran bahasa Indonesia di SMA kelas XI pada KD 3.24 merekonstruksi teks ceramah.

Kata Kunci: Sarkasme, Facebook PT Oy Indonesia, implikasi pembelajaran di SMA

Cara sitasi: Attazky, A. A., Triana, L., Anwar, S. (2020). Sarkasme dalam Unggahan dan Komentar pada Grup Facebook PT OY Indonesia dan Implikasinya terhadap Pembelajaran Bahasa Indonesia di SMA. Jurnal wahana pendidikan, 7 (2), 165 - 


\section{PENDAHULUAN}

Secara umum bahasa merupakan sebuah sistem arbiter dalam sebuah komunikasi yang dilakukan oleh sebuah masyarakat melalui kesapakatan bersama yang merujuk pada sebuah elemen beserta hubungan satu sama lainnya yang membentuk sebuah kesatuan yang hierarki. Kesatuan tersebut akan padu apabila penggunaan bahasa tersusun secara rapi baik tulisan maupun tuturan. Hal ini merupakan suatu keharusan yang dilakukan oleh seseorang ketika berkomunikasi, mengingat persepsi atau pemahaman tiap seseorang berbeda-beda ketika diajak berkomunikasi (Dardjowidodo, 2003:16)

Pendapat lain mengatakan bahwa bahasa adalah sebuah bunyi yang dihasilkan oleh alat ucap manusia yang memiliki bentuk dan makna. Alat ucap yang menghasilkan bahasa yakni paru, faring, laring, rongga hidung, rongga mulut, bibir, gigi, lidah, alveolum, palatum, velum dan uvula. Bentuk dan makna dapat menghasilkan sebuah keselarasan dalam berbahasa ketika tuturan antara dua individu sedang berlangsung. (Ramlan, 2014:1)

Bahasa memiliki peran penting bagi kehidupan masyarakat, dengan bahasa manusia bisa melakukan beragam macam hal, di antaranya melakukan komunikasi dengan sesamanya, menyampaikan informasi kepada orang lain, ataupun meminta pertolongan kepada sang pencipta. Bahasa sering digunakan dalam kehidupan sehari-hari manusia untuk melakukan interaksi sosial dengan sesama. Apabila bahasa belum diterapkan dalam kehidupan, maka manusia hanya mengenal gerak maupun simbol yang belum tentu tahu makna di baliknya.

Bahasa selalu berkembang serta sebagai alat komunikasi bahasa selalu mengikuti perkembangan teknologi dan budaya manusia yang menggunakannya. Ragam bahasa ilmiah adalah alat komunikasi dalam lingkup resmi atau ilmiah. Ragam bahasa ilmiah akan mengalami proses seiring dengan perkembangan teknologi dan budaya manusia yang menggunakannya itu (T Sunarya, 2019). Hal ini berarti proses pembakuan kata atau ejaan pun juga akan berjalan seiring dengan perjalanan waktu. Semakin zaman berubah, semakin fleksibel pula bahasa berubah. Tanpa adanya bahasa manusia akan megalami kesulitan dalam ilmu pengetahuan dan teknologi dan secara perlahan tidak tumbuh dan berkembang seperti sekarang ini.

Bahasa memiliki gaya tersendiri dalam pengucapannya dari setiap individu. Gaya dapat memberikan kesan berbeda apabila digunakan dalam melakukan komunikasi. Gaya atau khususnya gaya bahasa dikenal dalam retorika dengan istilah style. Gaya bahasa merupakan wujud keindahan dalam sebuah bahasa. Keraf (2006: 113) berpendapat bahwa gaya bahasa adalah cara menggunakan bahasa. Gaya bahasa yang baik adalah gaya bahasa yang mengandung beberapa unsur yakni kejujuran, sopansantun, dan menarik. Ade Nurdin, Yani Maryani, dan Mumu (2002: 21-30) berpendapat gaya bahasa dibagi menjadi lima golongan, yaitu: (1) gaya bahasa penegasan, yang meliputi repetisi, paralelisme; (2) gaya bahasa perbandingan, yang meliputi hiperbola, metonomia, personifikasi, perumpamaan, metafora, sinekdoke, alusio, simile, asosiasi, eufemisme, pars pro toto, epitet, eponym, dan hipalase; (3) gaya bahasa pertentangan mencakup paradoks, antithesis, litotes, oksimoron, hysteron, prosteron, dan okupasi; (4) gaya bahasa sidiran meliputi ironi, sinisme, innuendo, melosis, sarkasme, satire, dan antifarsis; (5) gaya bahasa perulangan meliputi aliterasi, antanaklasis, anaphora, anadiplosis, asonansi, simploke, nisodiplosis, epanalipsis, dan epuzeukis".

Seiring dengan perkembangan teknologi, fungsi dari sebuah internet mengalami perkembangan, yang awalnya hanya sebagai media bisnis, sekarang merambah ke media komunikasi. Salah satunya munculnya sebuah situs pertemanan yang di dalamnya memiliki sebuah fasilitas yakni chatting. fitur ini sangat berguna bagi setiap orang yang ingin melakukan interaksi secara langsung (real time). Facebook merupakan salah satu situs pertemanan yang dahulunya digunakan untuk percakapan antarmahasiswa di Universitas Harvard yang sekarang sudah menjadi situs pertemanan yang mendunia. Berkat fitur yang dimilikinya dari mulai news feed, posting, chating, add friend, create group dan lainnya membuat seluruh masyarakat dunia termasuk Indonesia berbondong-bondong untuk mendaftar ke laman facebook (Ichsan, 2009:9).

Seperti yang kita ketahui sarkasme ini sering digunakan dalam kehidupan sehari-hari saat sedang marah atau kesal bahkan anak usia remaja saja menggunakan kata-kata kasar saat bertutur kata atau 
menulis kalimat kepada temannya, contohnya dapat kita lihat dalam sebuah unggahan maupun komentar pada jejaring social mereka. Hal ini, sangat disayangkan bahwa generasi muda kurang memahami bahasa yang santun dan baik. Mereka tidak mengetahui apa yang mereka lakukan akan memberi dampak kepada sesama penutur maupun masyarakat yang tidak secara langsung memengaruhi lingkungannya. Mulyanto (2017: 207) mengungkapkan bahwa sarkasme adalah suatu gaya bahasa yang dimaksudkan untuk menyindir atau menyinggung seseorang atau sesuatu. Sarkasme dapat berupa penghinaan yang mengekspresikan rasa kesal dan marah dengan menggunakan kata-kata kasar. Gaya bahasa ini dapat melukai perasaan seseorang. Biasanya, sarkasme digunakan dalam konteks humor.

Ganie (2015:259) berpendapat bahawa sarkasme adalah gaya bahasa yang mengungkapkan sindiran secara kasar, bersifat mencemooh, menyakitkan hati, dan tidak enak didengar. Misalnya: mulut kamu harimau kamu. Bila dibandingkan dengan ironi, sarkasme merupakan gaya bahasa paling kasar karena mengandung celaan yang menyakitkan hati dengan menggunakan kata-kata yang tidak pantas.

Bahasa kasar atau sering disebut dengan sarkasme merupakan gaya bahasa yang berasal dari bahasa Yunani sarkasmeos, yang lebih jauh dari kata kerja sakasein yang berarti "merobek-robek daging seperti anjing", "menggigit bibir karena marah", atau "berbicara dengan kepahitan". Gaya bahasa ini merupakan ungkapan yang lebih bersifat negatif, artinya bila ia digunakan ketika melakukan komunikasi sedang berjalan, maka salah satu pihak akan merasa sakit hati (Keraf dalam Tarigan, 2013:92).

Seseorang yang mudah menuturkan bahasa sarkasme seringkali dipandang dengan manusia yang tidak memiliki tata karma atau dipandang negatif. Dengan sering mengejek, menyindir, dan menyinggung orang lain, mereka cenderung lebih terbuka kepada orang yang lebih dekat dengannya. Mereka yang memiliki sifat seperti ini akan lebih tidak peduli apa yang orang lain ucapkan. Mereka tipikal tidak peduli, tahan banting dan jago menghadapi masalah. Namun setiap orang akan belum bisa memahami hal tersebut karenan diakibatkan adala hal-hal penting dalam perubahan sosial yang menyangkut aspek-aspek sebagai berikut: perubahan pola pikir masyarakat, perubahan perilaku masyarakat, dan perubahan budaya materi (Bungin, 2006:91).

Widiastuti (2016:24) mengungkapkan gaya sarkasme dapat dibedakan menjadi beberapa jenis wujud sebagai berikut:

1. Sarkasme sifat

2. Sarkasme tindakan

3. Sarkasme hasil dari tindakan

4. Sarkasme himbauan

5. Sarkasme sebutan.

Berdasarkan penggolongan sarkasme tersebut, fungsi penuturan gaya bahasa sarkasme dibagi menjadi 10, yakni (1) bentuk penolakan, (2) bentuk penyampaian larangan, (3) bentuk penyampaian informasi, (4) bentuk penyampaian penegasan, (5) bentuk penyampaian pendapat, (6) bentuk penyampaian pertanyaan, (7) bentuk penyampaian perintah, (8) bentuk penyampaian persamaan, (9) bentuk penyampaian perbandingan, dan (10) bentuk penyampaian sapaan.

Berkenaan dengan hal itu, sarkasme menjadi salah satu topik yang menarik untuk diteliti. Penulis tertarik untuk melakukan penelitian terhadap salah satu grup facebook yang diikuti, yakni PT Oy Indonesia. Dalam grup tersebut, banyak sekali penggunaan sarkasme di dalamnya misalnya "sini gelud anjeng", "mati aja lu asw", "muka lu kaya babi" dan masih banyak ungkapan sarkasme lainnya. Alasan peneliti memilih sarkasme pada grup tersebut, karena di dalamnya terdapat beragam macam pengguna dari berbagai kalangan baik masih dalam pendidikan sampai bangku kuliah. Hal ini menunjukkan adanya keberagaman penggunaan bahasa, ketika melakukan interaksi antar pengguna. Tujuan penelitian ini adalah mendeskripsikan sarkasme dalam unggahan dan komentar pada grup facebook pt oy Indonesia dan mendeskripsikan implementasinya terhadap pembelajaran bahasa Indonesia di SMA. Penelitian ini diharapkan memberikan manfaat berupa perbendaharaan hasil penelitian yakni sarkasme terutama bagi pembelajaran bahasa Indonesia, menambah pengetahuan dalam perkembangan ilmu bahasa, linguistik umum dan memperkaya khasanah pengetahuan tentang ilmu bahasa. 


\section{METODE PENELITIAN}

Penelitian ini menggunakan metode kualitatif yaitu penelitian yang bersifat deskriptif analisis. Metode kualitatif yaitu metode penelitian yang tidak didesain atau dirancang menggunakan prosedur statistik. Penelitian ini bersifat deskriptif karena data yang diperoleh tidak dapat dituangkan dalam bentuk bilangan atau angka statistik. Peneliti memaparkan gambaran mengenai situasi yang diteliti dalam bentuk naratif. Peneliti mencatat dengan teliti dan cermat data yang berwujud tuturan yang berbentuk unggahan dan komentar, kemudian data tersebut dianalisis agar bisa ditarik kesimpulan umum.

Sumber data yaitu subjek dari penelitian untuk memperoleh data hasil penelitian. Sumber data diperoleh dari data utama yaitu Penggalan-penggalan tuturan dalam unggahan dan komentar pada grup facebook PT Oy Indonesia. Dalam penelitian ini wujud data berupa beberapa kata-kata sarkasme dari unggahan maupun komentar pada laman grup facebook PT Oy Indonesia.

Penyediaan data dalam penelitian ini mengunakan metode simak dan teknik catat. Teknik simak digunakan untuk mengetahui bentuk dan makna yang ada di dalam unggahan dan komentar pada grup facebook PT Oy Indonesia. Teknik catat digunakan untuk mendapatkan data tertulis yang digunakan sebagai bahan analisis, teknik catat dilakukan dengan cara mencatat unggahan dan komentar yang mengandung sarkasme di dalamnya.

Analisis data yang digunakan dalam penelitian ini adalah metode padan pragmatis. Metode padan pragmatis adalah metode yang menjadikan tanggapan atau reaksi mitra tutur sebagai penentunya. Metode ini digunakan untuk menentukan satuan kebahasaan menurut reaksi atau akibat yang terjadi atau timbul pada lawan atau mitra wicaranya ketika satuan kebahasaan itu dituturkan oleh pembicaranya (Kesuma, 2007:49). Metode ini mengidentifikasi satuan kebahasaan menurut reaksi akibat yang terjadi.

Teknik analisis data dalam penelitian ini menggunakan teknik pilah unsur penentu dengan daya pilah pragmatis. Menurut Sudaryanto (dalam kesuma, 2007:51) teknik pilah unsur penentu merupakan teknik pilah dimana alat yang digunakan adalah daya pilah yang besifat mental yang dimiliki oleh penelitinya. Daya pilah pragmatis adalah daya pilah yang menggunakan mitra tutur sebagai penentu. Hasil analisis data dalam penelitian kemudian disajikan dengan menggunakan metode informal yaitu penyajian hasil analisis data dengan kata-kata biasa (lih. Sudaryanto dalam Kesuma, 2007:71).

\section{HASIL DAN PEMBAHASAN}

Sarkasme dalam unggahan dan komentar pada grup facebook PT Oy Indonesia adalah objek penelitan. Penulis menganalisis dan mendeskripsikan tuturan sarkasme dalam unggahan dan komentar pada grup facebook PT Oy Indonesia dan implikasinya terhadap pembelajaran bahasa Indonesia di SMA. Sarkasme yang di temukan memiliki bentuk, maksud dan fungsinya masingmasing.

\section{Sarkasme dalam Unggahan dan Komentar pada Grup Facebook PT Oy Indonesia}

Hasil penelitian sarkasme dalam unggahan dan komentar pada grup facebook PT Oy Indonesia menunjukkan bahwa terdapat sarkasme yeng berbentuk: (1) sarkasme sifat (2) sarkasme tindakan, dan (3) sarkasme sebutan. Sarkasme tersebut memiliki maksud menyindir dan mengumpat, serta memiliki fungsi penegasan, pendapat dan pertanyaan. Berikut pembahasannya:

\section{Sarkasme Sifat}

Sarkasme sifat merupakan jenis kata kasar yang dituturkan dalam wujud sifat seseorang. Sifat yang dituturkan biasanya mengandung makna negatif dan tergolong kurang pantas apabila dituturkan, apalagi digunakan kepada orang yang lebih tua. Dalam sarkasme sifat, fungsi penegasan lebih banyak muncul dibandingkan dengan fungsi yang lain, karena penutur biasa menggunakan kata kasar dengan penggambaran nada yang tinggi atau tegas.

Data (1):

"Yang bilang bintang 1 ngotak tolol, kasihan dia driver, dia kerja, karna banyak kasus Opik jdi dia waspada ga ada yg salah". (Fathurr Keiichi) 
Pada data di atas terdapat kata sarkasme yakni "tolol" yang menunjukkan bahwa kata tersebut termasuk sarkasme sifat dan memiliki makna leksikal sangat bodoh. Penutur memberikan umpatan tersebut kepada mitra tutur karena, perilakunya yang dianggap kurang etis yaitu dengan memberikan penilaian negatif terhadap ojek daring yang selalu waspada akan pembelian fiktif dalam bertransaksi sehingga penutur memberikan umpatan bahwa mitra tutur mempunyai sifat bodoh. la menegaskan bahwa hal tersebut seharusnya dimaklumi, karena sejatinya transaksi daring lebih rentan dibandingkan transaksi luring yang melihat barang secara langsung antara penjual dan pembeli.

Data (2):

"GOBLOK TAPI TETEP DI EMBAT, KOK GOBLOK 2KALI" (Bagus Adi Santoso)

Pada data (2), sarkasme yang muncul dua kali dengan penyebutan yang sama yakni sifat seseorang "goblok" yang memiliki makna leksikal bodoh sekali. Penutur memberikan sindiran kepada mitra tutur dengan bentuk penegasan bahwa hal tersebut sudah salah sejak awal namun mitra tutur mengulangi kesalahan yang sama sehingga membuat para penutur lain merasa kesal akan sikap yang diambil penutur tersebut. Menurutnya mitra tutur bodoh ketika melakukan sesuatu yang memang sudah memiliki dampak negatif, sehingga penutur mengumpat dengan kata "goblok".

Data (3):

"Ikan hiu nabrak kaca, I love u buat yang baca, Ikan hiu masuk botol, ya gak bisa tolol" (Rifqizall)

Pada data (3) tersebut penutur menggunakan sarkasme sifat dengan mengumpat pada akhir kalimat dengan kata "tolol" yang memiliki makna leksikal sangat bodoh. Dengan menggunakan sedikit pantun, penutur memberikan respon kepada mitra tutur lain bahwa hal tersebut tidak bisa dilakukan karena cara tersebut sudah tidak bisa digunakan kembali. Penutur menggunakan kata kasar agar mitra tutur sadar diri akan tindakan yang dilakukannya. Sifatnya yang tidak bisa memahami situasi membuat penutur mengumpat kepadanya.

Data (4):

"Cape slurr nurutin nafsyu, sampe ulangan ke remedial semua bgst." (Alie)

Pada data tersebut penutur menggunakan kata sarkasme sifat yakni "bgst" yang merupakan singkatan dari kata "bangsat" yang memiliki makna leksikal kutu atau orang yang bertabiat jahat atau miskin dan gembel. Namun pada masyarakat kata tersebut memiliki makna kasar dengan maksud umpatan, karena mereka seringkali mendengar dalam bentuk umpatan bukan merujuk kesebuah benda ataupun mahluk hidup. Kata sarkasme tersebut merupakan bentuk sifat, karena seperti maknanya itu sendiri yakni bertabiat jahat, yang artinya penutur menganggap dirinya orang jahat karena tidak bisa membagi waktu secara efisien antara dunia nyata dengan dunia maya. Sifat penutur disebutkan bahwa ia bertabiat jahat karena tidak membagi waktunya dengan baik yang mengakibatkan hasil ulangannya tidak maksimal.

Data (5):

"bangke cokk mesen make vc 20k pesanan udh di donekan tapi makanan g nyampe ke gw". (Mohamad Yogs)

Pada data di atas bentuk sarkasme yang dituturkan penutur yakni sarkasme sifat. Data yang ada berisikan sarkasme sifat yaitu pada kata "bangke" yang merupakan plesetan dari "bangkai" yang memiliki makna leksikal tubuh yang sudah mati atau jasad. Hal ini merupkan kata yang kurang pantas ketika mereka bertutur kata di dunia internet. Penutur mengumpat kepada kurir karena pesanan yang seharusnya diantarkan tidak kunjung dating sehingga ia mengumpat dengan umpatan tersebut. Hal ini membuat penutur kecewa karena sudah susah payah mendapatkan kupon potongan harga, namun berujung pada kekecewaan.

\section{Sarkasme Tindakan}


Tindakan merupakan sesuatu hal yang dikerjakan atau perbuatan yang sedang dilakukan oleh seseorang dengan tujuan tertentu. Dalam kaitannya dengan sarkasme, tindakan seringkali digunakan ketika orang tersebut melakukan hal yang tidak perlu dilakukan dan biasanya menimbulkan rasa tidak nyaman apabila berada didekatnya. Tindakan merupakan langkah atau tata cara yang seharusnya dilakukan oleh seseorang untuk melakukan sesuatu. Sarkasme tindakan memiliki fungsi penyampaian informasi, karena dalam tuturannya penutur kerap kali menyinggung apa yang dilakukan mitra tutur. Berikut data yang peneliti temukan

Data (5):

"itu yg nge bacot pasti orang indo menyamar itulah knp orang INDOG jgn sampe msk group" besar gitu bahaya apa lagi masiu bocah labil ya pasti indo lama" di baned kaya sebelah". (Wibi)

Kutipan data di atas merupakan bentuk sarkasme tindakan dengan maksud menyindir. Kata yang muncul yakni "bacot" yang memiliki makna leksikal merujuk ke mulut yang artinya seseorang yang melakukan tuturan secara berlebihan dan tidak memiliki manfaat di dalamnya. Penutur memberikan tanggapan kasar kepada mitra tutur bahwa dirinya terlalu banyak bicara, dan mengumbar informasi grup tersebut karena dengan adanya kejadian tersebut bisa menimbulkan hilangnya grup tersebut, sehingga penutur menggunakan kata kasar tersebut.

Data (6):

"mampos kebanyakan pansos jahanam waiting for you brother". (Baad)

Pada data di atas, penutur memberikan umpatan kepada penutur lain yang melakukan tindakan mencari sensasi dengan kata "pansos" yang memiliki makna leksikal usaha yang dilakukan untuk mencitrakan diri sebagai orang yang mempunyai status sosial tinggi dengan cara mengunggah foto, tulisan dan sebagainya di media maya. Penutur juga menggunakan kata "mampos" dan "jahanam" yang memiliki makna leksikal mati di tempat yang terkutuk, atau tempat berapi didalam akhirat. Penutur memberikan umpatan tersebut kepada mitra tutur yang selalu mengunggah hal-hal yang berbau pansos atau unjuk gigi bahwa dirinya bisa melakukan sesuatu hal yang tidak bisa dilakukan oleh orang lain.

Data (7):

"Kmren yang bilang harga emas lebaran naik tembus sejuta /gr sapa y?? Rene tak tapok lambemu" (Aviv Wahyu Rosyadi)

Data tersebut menunjukkan bahwa penutur merasa kecewa kepada mitra tutur atas informasi yang kurang valid atau hoax. Penutur menggunakan sarkasme berupa umpatan dalam bahasa Jawa yakni "tapok" yang dalam KBBI kata tersebut merupakan istilah lain dari kata tampar yakni pukul (dengan telapak tangan) dan "lambemu". Dalam KBBI kata tersebut merupakan istilah lain dari kata mulutmu yakni rongga di muka, tempat gigi dan lidah, untuk memasukan makanan (pada manusia dan binatang). Penutur akan menampar apabila ia bertemu dengan mitra tutur yang telah memberikan informasi bohong atau hoax.

Data (8):

"W lebih suka orang yang suka ngemis ngemis minta saldo RP1 Dr pada mereka yang suka ngeripp Karna menurut gw mereka yang suka ngeripp di medsos pake akun palsu itu pecundang banci lo anjingg Klo mau dpt duit itu usaha begokk Jangan nipu." (Kynthod)

Pada data di atas penutur menggunakan kata kasar tindakan yang ditujukan kepada mitra tutur yakni "ngemis-ngemis" yang memiliki makna perbuatan meminta-minta kepada seseorang dengan memelas, pada tuturan ini mitra tutur yang diumpat meminta minta kepada anggota lain untuk memberikan dana. Kemudian sarkasme sifat muncul yakni pada kata "pecundang banci" yang memiliki makna leksikal seseorang yang melakukan perubahan jenis kelamin dengan sengaja dan biasanya memiliki maksud untuk perbaikan ekonomi, salah satunya mitra tutur tersebut.

Selain sarkasme ngemis-ngemis, sarkasme sebutan ada pada kata "anjing" yang memiliki makna leksikal binatang peiharaan yang bertugas menjaga rumah dan sarkasme sifat 
dengan kata "goblok" yang memiliki makna bodoh sekali. Dalam masyarakat Indonesia, kata anjing dianggap kasar, karena perilakunya yang buas dan sering mengganggu kehidupan warga, sehingga umpatan kata tersebut termasuk tergolong kasar. Kata kasar tersebut bukanlah hal yang baik apabila dituturkan dalam kondisi apapun, karena sedikit saja kata kasar akan mengakibatkan mitra tutur sakit hati.

Data (9):

"Wkwk 10 perak buat apaan? 0 ada yg seneng bilang "done makasih" mau marah takut batal kan babi tuh ilham kentod" (Sutrisno Sutrisno)

Pada data tersebut penutur menyindir penutur dengan kata sarkasme tindakan yakni "kentod" yang merupakan singkatan dari kencan total yang merupakan tindakan/kegiatan yang dilakukan laki-laki dan perempuan yang sudah melewati norma, yang artinya hal tersebut tabu dan tidak pantas apabila kata tersebut dituturkan. Norma yang dimaksud merupakan aturan pergaulan yang harus ditaati demi kenyamanan dalam bersosialisasi di dalam masyarakat.

Selain tindakan, sarkasme sebutan muncul yakni pada kata "babi" yang memiliki makna leksikal binatang yang bermoncong panjang, berkulit tebal dan berbulu kasar. Dalam masyarakat Indonesia, babi dianggap kata kasar karena dianggap binatang yang menjijikan dan kotor sehingga sering digunakan sebagai umpatan. Penyebutan binatang kerapkali digunakan para penutur dengan tujuan agar penutur lain tahu bahwa ia sedang marah atau sering disebut dengan "ngegas".

Data (10):

"Halah bacot pantek Gasuka group gw minggat aja lu anjing banyak bacot Gada garapan koar2 taik Salahin orang YG GAK SUKA GROUP INI MINGGAT CARI SANA GROUP YG LAIN Bacot iya". (M Yudha)

Pada data tersebut penutur menggunakan beberapa kata sarkasme dalam tuturannya yakni tindakan yang dilakukan mitra tutr yakni "bacot" yang memiliki makna leksikal merujuk ke mulut yang artinya seseorang yang melakukan tuturan secara berlebihan dan tidak memiliki manfaat di dalamnya, "pantek" yang memiliki makna leksikal pasak,

Selain itu, sarkasme sebutan muncul pada kata "anjing" yakni memiliki makna leksikal binatang yang bertugas menjaga rumah dan "taik" yang berasal dari Bahasa Jawa yang dalam $\mathrm{KBBI}$ kata tersebut adalah tahi dan memiliki makna leksikal ampas makanan dari dalam perut yang keluar melalui dubur. Dalam masyarakat Indonesia, kata anjing dianggap kasar, karena perilakunya yang buas dan sering mengganggu kehidupan warga, sehingga umpatan kata tersebut termasuk tergolong kasar. Hal ini sudah sepatutnya tidak digunakan dalam berbagai tuturan karena akan menimbulkan kesalahpahaman antara penutur dan mitra tutur. Penutur sebagai pendiri grup memberikan sindiran kepada mitra tutur karena tidak menerima grup apa adanya, mereka selalu banyak bicara omong kosong, mengeluh dan selalu menyalahkan pendiri grup, sehingga membuat penutur menggunakan kata kasar dalam unggahannya.

\section{Sarkasme Sebutan}

Sebutan adalah suatu kegiatan yang memberi label, nama atau suatu hal yang berkaitan dengan pemberian simbol tertentu kepada suatu benda. Dalam kaitannya dengan sarkasme, penyebutan dilakukan dengan cara memberikan label kepada sesorang dengan nama binatang atau hal-hal yang sering kurang pantas apabila dibandingkan dengan benda tersebut. Pada tuturan sarkasme penyebutan, penutur lebih menitikberatkan kepada fungsi pendapat, yakni memberikan komentar terhadap apa yang dilakukan oleh mitra tutur. Berikut data yang peneliti temukan

Data (11):

"Anjirr naggung amat 25k Mending gw nge hode di Malay bisa dapat 30RM - 200RM". (llham)

Pada data di atas, terdapat bentuk sarkasme penyebutan yakni "Anjirrr" yang merupakan plesetan dari kata binatang "anjing" yang memiliki makna leksikal binatang yang bertugas 
menjaga rumah. Dalam masyarakat Indonesia, kata anjing dianggap kasar, karena perilakunya yang buas dan sering mengganggu kehidupan warga, sehingga umpatan kata tersebut termasuk tergolong kasar. Penutur seringkali menyingkat atau memberi plesetan pada beberapa kata dengan tujuan memberikan nuansa yang berbeda namun memiliki makna yang sama.

Pada data di atas juga terdapat kata kasar yaitu "hode" atau istilah lain dari penipuan dengan cara menyamar dan berganti jenis kelamin dengan tujuan memeras anggota lain. Penutur mengunoar dengan menyebut mitra tutur sebagai anjing karena perbuatannya tidak seharusnya ia lakukan.

\section{Data (12):}

"Anjirrrr @ ni orang ngaku" Bukalapak terus minta otp ke gue asw mana gue dapat 3 juta Anji rrrr". (Kang Bdr)

Pada kutipan data tersebut penutur menggunakan kata sarkasme berbentuk penyebutan dengan penyampaian informasi yakni "anjir" dan "asw". Keduanya merupakan plesetan dan singkatan kata dari "anjing" yang memiliki makna leksikal binatang yang bertugas menjaga rumah. Dalam masyarakat Indonesia, kata anjing dianggap kasar, karena perilakunya yang buas dan sering mengganggu kehidupan warga, sehingga umpatan kata tersebut termasuk tergolong kasar. Penutur mengumpat kepada mitra tutur dengan sebutan anjing karena akan melakukan penipuan dengan atas nama perusahaan aplikasi tersebut. Dalam dunia maya hal ini seringkali terjadi kepada pengguna yang sudah menyebar nomor teleponnya.

Data (13):

"Tau kontol ga? Temui gw ama yang buat status. Mau gua gaplok mulutnya". (Mamank Garox)

Pada data tersebut penutur menggunakan kata sarkasme sebutan yakni pada kata "kontol" yang memiliki makna leksikal alat kemaluan laki-laki. Penutur mengumpat kepada mitra tutur yang melakukan sesuatu yang dianggap kurang pantas dengan sebutan alat vital laki-laki, ketika mengunggah sesuatu dilaman internet dan hal tersebut bisa memancing amarah anggota lain, termasuk si penutur. Bagi masyarakat Indonesia, kata tersebut merupakan hal yang tabu apabila digunakan dalam bertutur kata. Kata tersebut juga berasal dari bahasa Jawa dan sering digunakan ketika mengumpat ataupun menyindir kepada seseorang.

Sarkasme tindakan juga muncul pada data tersebut yakni kata "gaplok" yang berasal dari bahasa jawa "tampar" yang memiliki makna leksikal pukul (dengan telapak tangan). Penutur ingin menampar mitra tutur karena perbuatannya.

Data (14):

"Yaelahh ginian doang marah baperan amat anjing wokwokwow". (Patan)

Pada data di atas penutur menyindir penutur lain dengan kata sarkasme penyebutan kata binatang yakni "anjing" yang memiliki makna leksikal binatang menyusui yang biasa dipelihara untuk menjaga rumah. Dalam masyarakat Indonesia, kata anjing dianggap kasar, karena perilakunya yang buas dan sering mengganggu kehidupan warga, sehingga umpatan kata tersebut termasuk tergolong kasar. Dalam grup facebook ataupun media pertemanan lainnya penyebutan kata tersebut seringkali digunakan ketika ingin mengumpat maupun menyindir kepada seseorang. Hal tersebut mereka anggap wajar dan tidak akan berdampak apapun. Padahal apabila ditelurusi lebih dalam lagi, kata sarkasme apabila ditujukan kepada seseorang yang mempunyai karakter tertutup, akan berdampak sangat besar baik secara mental maupun psikologis. Penutur mengumpat kepada mitra tutur dengan menyebutnya anjing karena terbawa suasana unggahan dari pengguna lain.

Data (15):

"Njeerr udah bahagia bebas tagihan sampe bulan Agustus eeh ditarik lagi. Katanya promo gmna sih" (Ahmad Andika)

Pada data tersebut, penutur menggunakan kata kasar sebutan yakni pada kata "Njerr" yang merupakan plesetan dari kata "anjing" yang memiliki makna leksikal binatang yang 
bertugas menjaga rumah. Dalam masyarakat Indonesia, kata anjing dianggap kasar, karena perilakunya yang buas dan sering mengganggu kehidupan warga, sehingga umpatan kata tersebut termasuk tergolong kasar. Penutur merasa kecewa dengan mengumpat pada pihak aplikasi. Pada hari minggu bulan Mei, aplikasi lazada mengalami bug atau celah di dalamnya, token listrik berubah harga yang awalnya sesuai harga umum, menjadi jatuh tidak rasional. Penutur mendapat surel balasan mengenai tagihan agar dibayar kembali sesuai dengan harga asli sehingga penutur merasa dirugikan dan menyebutnya anjing karena kelalaian pengelola aplikasi, namun sebenarnya hal seperti ini merupakan kesalahan sistem dan penutur seharusnya tidak memanfaatkannya secara berlebihan.

Data (16):

"Anjirrrr 0 ni orang ngaku" Bukalapak terus minta otp ke gue asw mana gue dapat 3 juta Anji rrrr". (Kang Bdr)

Pada kutipan data tersebut, penutur menggunakan kata sarkasme berbentuk penyebutan dengan penyampaian informasi yakni "anjir" dan "asw" yang keduanya merupakan plesetan dan singkatan kata dari "anjing" yang memiliki makna leksikal binatang yang bertugas menjaga rumah. Dalam masyarakat Indonesia, kata anjing dianggap kasar, karena perilakunya yang buas dan sering mengganggu kehidupan warga, sehingga umpatan kata tersebut termasuk tergolong kasar. Penutur mengumpat kepada mitra tutur dengan sebutan anjing karena akan melakukan penipuan dengan atas nama perusahaan aplikasi tersebut. Dalam dunia maya hal ini seringkali terjadi kepada pengguna yang sudah menyebar nomor teleponnya secara langsung tanpa memedulikan hal yang nantinya akan membuat dirinya mengalami kerugian.

\section{Implikasi Hasil Penelitian}

Implikasi merupakan penerapan pada bidang tertentu. Dalam Kamus Besar Bahasa Indonesia $\mathrm{V}$, implikasi memiliki makna keterlibatan atau penelitian makin terasa manfaat dan kepentingannya. Apabila penelitian memiliki implikasi di dalamnya maka penelitian tersebut lebih bermanfaat dibanding dengan penelitian yang tidak memiliki implikasi di dalamnya. Hal seperti ini biasanya dikaitkan dengan bidang pendidikan yakni pada proses pembelajaran.

Pembelajaran merupakan suatu proses interaksi antara individu yang memiliki pengetahuan lebih kepada khalayak umum dengan tujuan memberikan informasi yang dibutuhkan oleh individu lain. Selain informasi yang disampaikan, pembelajaran juga memiliki kegiatan lainnya yang bermanfaat, diantaranya adanya interaksi lebih antara pemateri dengan mitra tutur, diskusi yang bisa dilakukan oleh antar mitra tutur dengan tugas yang diberikan oleh pemateri, maupun melatih kreatifitas dan kemampuan berkomunikasi didepan umum.

Berbicara mengenai komunikasi, manusia pastinya tidak akan lepas dengan kegiatan berkomunikasi. Dalam KBBI V komunikasi adalah pengiriman dan penerimaan pesan atau berita antara dua orang atau lebih sehingga pesan yang dimaksud dapat dipahami. Pesan yang dituturkan akan lebih dipahami apabila mitra tutur dan penutur saling memahami apabila bahasa yang digunakan merupakan universal, sehingga tidak akan terjadi salah paham.

Seperti halnya dalam kegiatan ceramah. Penceramah akan melakukan komunikasi dengan satu arah kepada para khalayak. Informasi yang disampaikan harus menarik dan mudah dipahami agar khalayak tidak merasa bosan bahkan tidur. Dengan memberi informasi yang tepat dan sedikit gelitik tawa, pastinya pendengar akan lebih bisa memahami apa yang disampaikan oleh pemateri.

Standar kompetensi yang penulis rencanakan dalam rencana pelaksanaan pembelajaran ini adalah menulis, yaitu kompetensi dasar 3.24 kelas XI pada semester 1 yakni membuat teks ceramah dengan memperhatikan struktur dan aspek kebahasaan dengan cermat. Maksud dari membuat teks ceramah dengan memperhatikan struktur dan aspek kebahasaan dengan cermat adalah peserta didik membuat teks ceramah dengan materi yang sebelumnya disampaikan oleh pendidik atau guru baik itu secara langsung maupun tidak langsung, sehingga ketika peserta didik diberikan tugas oleh guru maka peserta didik dapat memahaminya dan mengerjakannya dengan 
baik dan benar. Kompetensi dasar dalam pembelajaran ini adalah mengonstruksi ceramah berkaitan bidang pekerjaan dengan memperhatikan aspek kebahasaan dan menggunakan struktur yang tepat. Dengan memerhatikan aspek kebahasaan peserta didik diharapkan dapat menemukan referensi yang tepat dan benar, sehingga ketika teks ceramah dibuat, tidak mengandung unsur negatif seperti halnya kata sarkasme.

Berdasarkan uraian mengenai standar kompetensi di atas maka peserta didik diharapkan dapat menentukan tema yang tepat digunakan ketika membuat teks ceramah dan penuturan bahasa yang baik dan benar serta sesuai kaidah penyusunan teks ceramah, sehingga materi yang disampaikan oleh pendidik dapat diterima dengan baik.

\section{SIMPULAN}

Sarkasme yang terdapat dalam grup facebook PT Oy Indonesia, yakni memiliki bentuk (1) sarkasme sifat, (2) sarkasme tindakan, dan (3) sarkasme sebutan. Dari ketiga bentuk tersebut sarkasme, data yang ditemukan memiliki maksud yang sama yakni mengumpat dan menyindir dengan makna yang berbeda-beda di dalamnya. Hasil penelitian "sarkasme dalam unggahan dan komentar pada grup facebook PT Oy Indonesia" dapat diimplikasikan pada kelas XI SMA semester I pada materi dengan KD 3.24 yakni teks ceramah. Aspek pembelajaran sarkasme pada pembelajaran teks ceramah pada mata pelajaran bahasa Indonesia di SMA sangat bermanfaat untuk meningkatkan kesantunan berbahasa dan kreatifitas peserta didik dalam menentukan kosakata yang baik dan benar, sehingga memberikan khasanah dan sumbangsih bagi terbentuknya pandangan baru tentang pentingnya menggunakan bahasa Indonesia yang tepat.

Setelah analisis dilakukan, hasil lainnya juga diperoleh diantaranya pada grup tersebut, selain sarkasme sangat jarang gaya bahasa lain digunakan akan tetapi muncul sebuah pantun di dalamnya. Hal itu menunjukkan bahwa dalam sebuah media pertemanan daring ada banyak keragaman di dalamnya namun hanya sebagian saja bukan semuanya memiliki karakteristik yang sama dengan grup yang peneliti teliti.

Alasan dan dampak yang didapat ketika peneliti menganalisis lebih dalam lagi, seluruh penutur hampir memiliki jawaban yang sama yakni hanya sebatas mengekspresikan perasaan diri, walaupun terkesan kasar mereka mengganggap hal tersebut wajar karena di dunia digital mereka bebas melakukan apapun di dalamnya contohnya mengungkapkan apa yang mereka rasa. Untuk dampak yang ditimbulkan, mereka mengganggap itu tergantung pribadi penutur lainnya. Apabila hal tersebut memang kurang pantas dituturkan, maka jangan ditiru perilakunya. Namun apabila hal tersebut wajar dan dapat digunakan semestinya maka hal tersebut bisa digunakan dengan batasan yang normal sampai menimbulkan dendam dan perdebatan.

Saran dari peneliti atas penelitian ini yaitu guru bahasa Indonesia sekaligus sebagai pengajar bahasa dan sastra hendaklah memberikan pengajaran yang maksimal sehingga peserta didik tidak hanya memahami sastra saja namun bahasa juga perlu diberikan kepada peserta didik agar manfaat dari pembelajaran bisa diterima secara seimbang.

\section{REKOMENDASI}

Sebaiknya penggunaan sarkasme agar diminimalisir dalam segala situasi apapun, karena selama zaman mengalami perubahan, maka tingkat pelanggaran bahasa akan semakin tinggi. Untuk itu dalam pembelajaran, baik pendidik maupun calon pendidik harus segera menerapkan pola pembelajaran yang mengarahkan peserta didik untuk menggunakan bahasa secara baik dan benar ketika melakukan komunikasi atau pun mengunggah sesuatu pada laman media sosial.

\section{UCAPAN TERIMA KASIH}

Terima kasih kepada semua pihak yang selalu memberikan arahan mengenai apa yang diperlukan dalam penulisan karya tulis ilmiah dan juga yang telah membantu pelaksanaan penelitian. 


\section{DAFTAR PUSTAKA}

Bungin, B. (2006). Sosiologi Komunikasi. Jakarta: Kencana.

Dardjowidodo, S. (2003). Psikolinguistik: Pengantar Pemahaman Bahasa Manusia. Jakarta: Yayasan Pustaka Obor Indonesia.

Ganie, T. N. (2015). Buku Induk Bahasa Indonesia. Yogyakarta: Angkasa.

Ichsan, A. M. (2009). Kupas Habis Facebook dan 10 Situs Gaul Terpopuler. Jakarta: Kriya Pustaka.

Keraf, G. (2006). Diksi dan Gaya Bahasa. Jakarta: Gramedia.

Kesuma, T. M. J. (2007). Pengantar (Metode) Penelitian Bahasa. Yogyakarta: Carasvatibooks.

Nurdin, A. dkk. (2002). Intisari Bahasa dan Sastra Indonesia untuk Kelas 1,2,3 SMU. Bandung: CV Pustaka setia.

Ramlan. (2014). Suka Berbahasa Indonesia. Jakarta: Gaung Persada Press Group.

Sudaryanto. (1993). Metode dan Aneka Teknik Analisis Bahasa. Yogyakarta: Duta Wacana University.

Sunarya. (2019). Upaya Meningkatkan Kemampuan Membaca Teks Berita Dengan Menggunakan Teknik Bermain Peran (Penelitian Tindakan Kelas Di Kelas VII-A SMP Negeri 14 Tasikmalaya). Jurnal Wahana Pendidikan 5 (4), 81-86

Tarigan, H. G. (2013). Pengajaran Gaya Bahasa. Bandung: Angkasa.

Widiastuti, S. (2016). "Gaya Bahasa Sarkasme Roman Ser! Rahda Cocak Karya Suprapto Brata" Disertasi Universitas Negeri Semarang. 
Jurnal Wahana Pendidikan, 7(2), 165-176, Agustus 2020 P-ISSN: 2355-2425 dan E-ISSN : 2715-6796 